\title{
Implementasi Virtual Router Redundancy Protocol Untuk Meningkatkan Kinerja Jaringan Direktorat Hukum Angkatan Darat (DITKUMAD) Jakarta
}

\author{
Yunita Maudy $\left.{ }^{*}\right)$, Aziz Setyawan Hidayat ${ }^{2)}$, Eva Rahmawati ${ }^{3)}$ \\ ${ }^{1) 3}$ Sekolah Tinggi Manajemen Informatika dan Komputer Nusa Mandiri \\ ${ }^{2)}$ Universitas Bina Sarana Informatika PSDKU Kota Tegal \\ ${ }^{*}$ Correspondence author: yunitamaudy85@gmail.com, DKI Jakarta, Indonesia
}

\begin{abstract}
Abstrak
Kegagalan pada jaringan terdiri dari kegagalan perangkat dan kegagalan link. Kegagalan perangkat berarti bahwa perangkat jaringan itu sendiri sedang down yang bisa berupa kegagalan pada switch atau router. Kegagalan perangkat bisa terjadi pada switch atau router maka jaringan tersebut akan down karena tidak ada yang bisa meneruskan paket. Karena switch atau router merupakan perangkat inti dari jaringan dan yang menghubungkan antar segment yang berbeda. Pada saat terjadi kegagalan jaringan yang di sebabkan oleh perangkat jaringan yaitu router, bagian IT network akan memperbaikinya secara manual dan memerlukan waktu yang cukup lama. Hal tersebut tentunya mengurangi kinerja pada suatu jaringan komputer, bila tidak adanya peralihan jaringan secara cepat dan otomatis. Oleh karena itu, dibutuhkan Implementasi Virtual Router Redundancy Protocol (VRRP) untuk meningkatkan kinerja jaringan. Dengan adanya VRRP dapat mengatasi kegagalan suatu jaringan yang disebabkan oleh perangkat jaringan.
\end{abstract}

Kata Kunci: Implementasi, VRRP, Router, Jaringan

\begin{abstract}
Network failure consists of device failure and link failure. Device failure means that the network device itself is down which can be a switch or router failure. Device failure can occur on a switch or router then the network will be down because no one can forward packets. Because a switch or router is the core device of the network and which connects between different segments. In the event of a network failure caused by a network device that is a router, the IT network will fix it manually and take quite a long time. This certainly reduces performance on a computer network, if there is no network switching quickly and automatically. Therefore, a Virtual Router Redundancy Protocol (VRRP) Implementation is needed to improve network performance. With the existence of VRRP can overcome the failure of a network caused by network devices.
\end{abstract}

Keywords: Implementation, VRRP, Router, Network

\section{PENDAHULUAN}

Dengan semakin majunya kebutuhan informasi, komunikasi dan transfer data yang cepat dan juga didukung oleh kemampuan komputer yang semakin canggih pada perkembangan zaman terutaman pada era komputerisasi dimana pemanfaatan waktu seefisien dan sebaik mungkin menjadi utama dalam mempermudah penyelesaian kerja. Pesatnya perkembangan teknologi terutama jaringan internet saat ini membuat semakin mudahnya individu, kalangan masyarakat dan perusahaan untuk mempercepat pengolahan data, penyimpanan data, dan pengembangan bisnis bahkan transaksi dalam bentuk online. Untuk memaksimalkan pengoperasian jaringan, diperlukan adanya manajemen jaringan yang baik, sehingga kesalahan yang sekecil mungkin dapat dihindari. 
Dalam memberikan pelayanan tersebut maka dibutuhkan layanan jaringan yang tersedia 24 jam dalam sehari untuk melayani mereka yang membutuhkan, demi kepentingan organisasi. Selain aktif layanan jaringan selama 24 jam non stop, pada kantor Direktorat Hukum Angkatan Darat (Ditkumad) Jakarta, juga banyaknya aliran data yang dilakukan dalam mengakses jaringan, tentu akan terjadi beberapa trouble pada jaringan. Salah satu yang sering terjadi adalah beban pada router yang menyebabkan terganggunya stabilitas pada jaringan. Dikarenakan beban yang diterima terlalu berat maka akan mengurangi performa dari router itu sendiri.

Menurut (Gustina et al., 2017)“ Router adalah perangkat yang berfungsi untuk menghubungkan satu jaringan dengan jaringan lain yang memakai protokol komunikasi yang berbeda. Router secara umum adalah sebuah alat yang mengirimkan paket data melalui suatu jaringan atau internet menuju tujuannya, melalui sebuah proses yang dikenal sebagai penghalaan. Proses penghalaan terjadi pada lapisan 3 (lapisan jaringan seperti internet Protocol) dari protokol tumpukan (stack protocol) tujuh lapis OSI”.

Untuk itu performa pada sebuah jaringan komputer pada kantor Direktorat Hukum Angkatan Darat (Ditkumad) Jakarta haruslah mempunyai performa atau kualitas yang sangat baik dalam hal berkomunikasi dan pertukaran data. Tentunya dalam penyaluran data dibutuhkan suatu sistem yang dapat berjalan efektif dengan mengurangi atau mencegah putusnya koneksi dalam sebuah jaringan komputer. Karena apabila terjadi kerusakan pada jaringan tersebut, juga dapat berakibatkan pada terhambatnya kinerja karyawan dalam mengakses atau mengirim data. Maka dari itu butuh alternatif pemecahan masalah berupa router backup atau yang lebih dikenal dengan Virtual Router Redundancy Protocol (VRRP). Menurut (Choirullah, Anif, \& Rochadi, 2017) menyatakan bahwa "Virtual Router Redundancy Protocol (VRRP) Merupakan protocol virtual router yang bertanggung jawab menjalankan fungsi router backup saat kondisi router master mengalami kegagalan jaringan". Menurut (Raharjo, Pernando, \& Fauzi, 2019) menyatakan bahwa "VRRP yaitu menjaga dari terputusnya jalur komunikasi dan menjaga dari matinya router utama. Hal tersebut dikarenakan protokol VRRP menggunakan dua router yang berfungsi sebagai router master dan router backup".

Protocol VRRP didesain untuk menyediakan proses transisi yang cepat dari router backup ke router utama sehingga meminimalkan gangguan pada layanan di kantor Direktorat Hukum Angkatan Darat (Ditkumad) Jakarta. Penulis membuat router backup untuk mengantisipasi kasus kerusakan pada raouter utama. Dengan cara menerapkan metode virtual router redundancy protocol (VRRP). Untuk diterapkan sebagai redundant router 
guna meminimalisir downtime pada jaringan yang berada di kantor Direktorat Hukum Angkatan Darat (Ditkumad) Jakarta.

\section{METODE}

Dalam penelitian ini penulis melakukan pengumpulan data menggunakan beberapa metode, antara lain:

\section{Observasi}

Penulis melakukan mengumpulan data secara langsung melalui pengamatan dan pencantatan dilapangan mengenai alat-alat yang digunakan dalam konfigurasi jaringan internet pada Direktorat Hukum Angkatan Darat (Ditkumad) Jakarta.

2. Wawancara

Penulis melakukan proses tanya jawab secara bertatap muka dan mendengarkan secara langsung informasi yang dibutuhkan. Dalam hal ini penulis melakukan wawancara kepada kepala IT Jaringan Infolahta di Direktorat Hukum Angkatan Darat (Ditkumad) Jakarta.

3. Studi Pustaka

Penulis melakukan studi pustaka dengan cara pengambilan data dari jurnal, buku-buku, artikel melalui media internet atau perpustakaan yang terkait dengan pelaksanan riset yang berguna untuk membantu memcahkan masalah yang dihadapi.

Penelitian ini dilakukan mulai dari perancangan sistem jaringan sampai dengan pengujian jaringan pada penerapan failover gateway menggunakan protokol virtual router redundancy protocol (VRRP) pada mikrotik router, akan dijabarkan dalam beberapa bagian mulai dari analisa kebutuhan sistem, desain, implementasi sampai dengan pengujian. Analisa dan perancangan yang diterapkan penulis pada skripsi ini menurut (Kuswanto \& Rahman, 2019) yaitu :

1. Analisa Kebutuhan

Observasi langsung pada kantor Direktorat Hukum Angkatan Darat (Ditkumad) Jakarta. Mengamati dan memahami semua kondisi struktur jaringan pada seluruh gedung khususnya pada lantai 4 Direktorat Hukum Angkatan Darat (Ditkumad) Jakarta. Menganalisis dan memberikan solusi dalam memecahkan masalah pada hasil observasi yang telah dilakukan.

2. Desain

Merupakan tahap selanjutnya dari analisa kebutuhan. Dimana tujuan sistem diimplementasikan berdasarkan analisis dan arsitektur jaringan komputer yang sudah ada di Direktorat Hukum Angkatan Darat (Ditkumad) Jakarta, maka diperlukan desain 
jaringan yang sesuai dengan motode Virtual Router Redundancy protocol (VRRP) yang akan diimplementasikan.

3. Test

melakukan pengujian terhadap router yang telah dirancang untuk menilai keberhasilan router redundancy tersebut. Suatu router redundancy protocol dinilai sukses apabila router bekerja dan berjalan berdasarkan sistem kerja yang telah dirancang dan dinilai gagal apabila router tidak bekerja sebagaimana mestinya.

4. Implementasi

Penerapan konfigurasi Virtual Router Redundancy protocol (VRRP) dengan menggunakan winbox, virtual box, dan Iso mikrotik.

\section{HASIL DAN PEMBAHASAN}

Menurut (Ratna, 2017)” Topologi jaringan adalah seperangkat komputer yang saling terhubung secara bersamaan satu dengan lainnya dengan tujuan utama, yakni untuk saling berbagi sumberdaya. Internet adalah salah satu sumberdaya yang saat ini banyak digunakan di dalam suatu jaringan computer".

Dalam rancangan jaringan usulan yang penulis rancang untuk Direktorat Hukum Angkatan Darat (Ditkumad) Jakarta tetap menggunakan topoloi jaringan yang masih berjalan di Direktorat Hukum Angkatan Darat (Ditkumad) Jakarta menggunakan 2 jenis topologi yaitu bus dan star, digabungkan menjadi topologi hybrid dimana topologi ini yang menghubungkan beberapa komputer dengan menggunakan perangkat yaitu $H u b$ atau Switch.

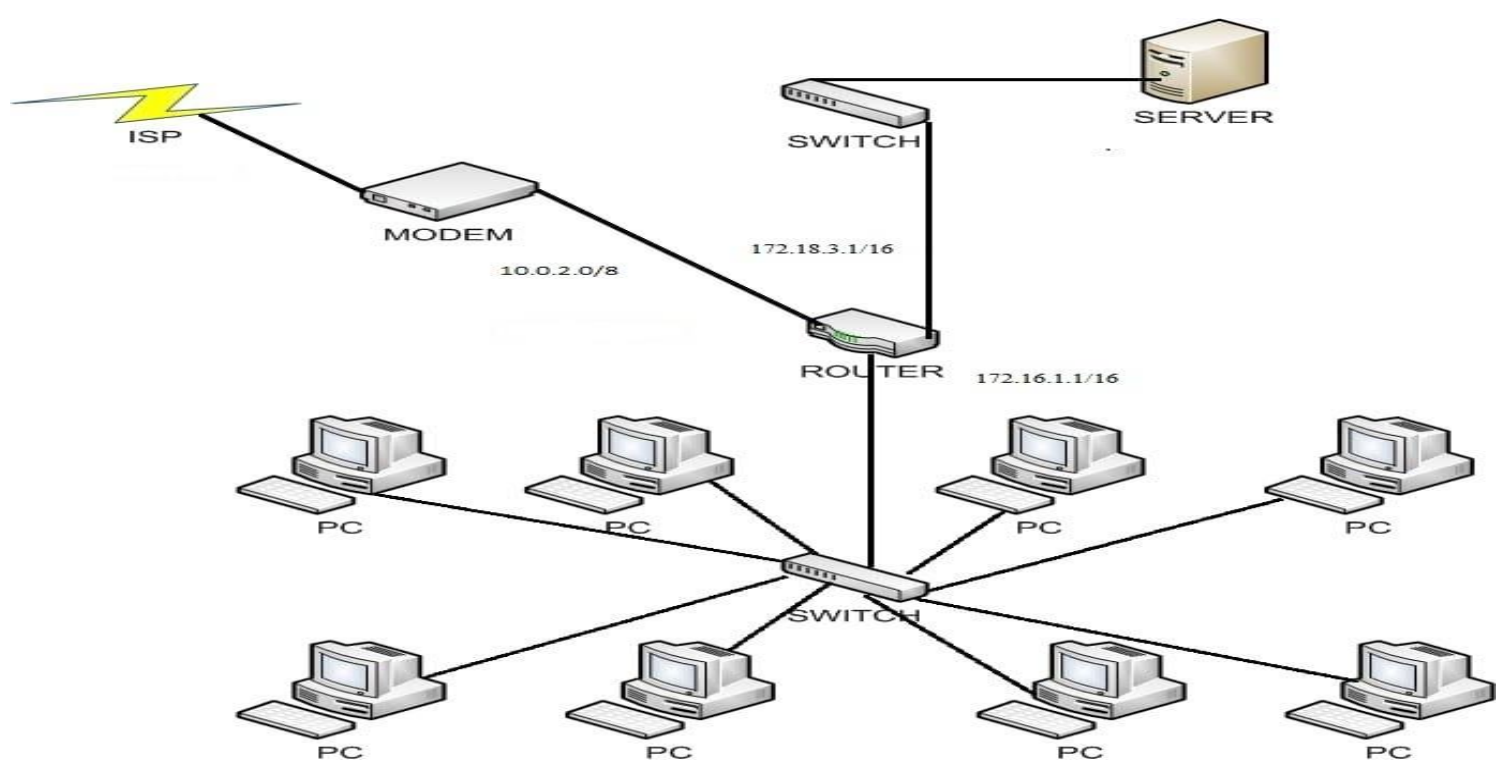

Gambar 1. Skema Jaringan

Sumber : Direktorat Hukum Angkatan Darat (Ditkumad) Jakarta. 


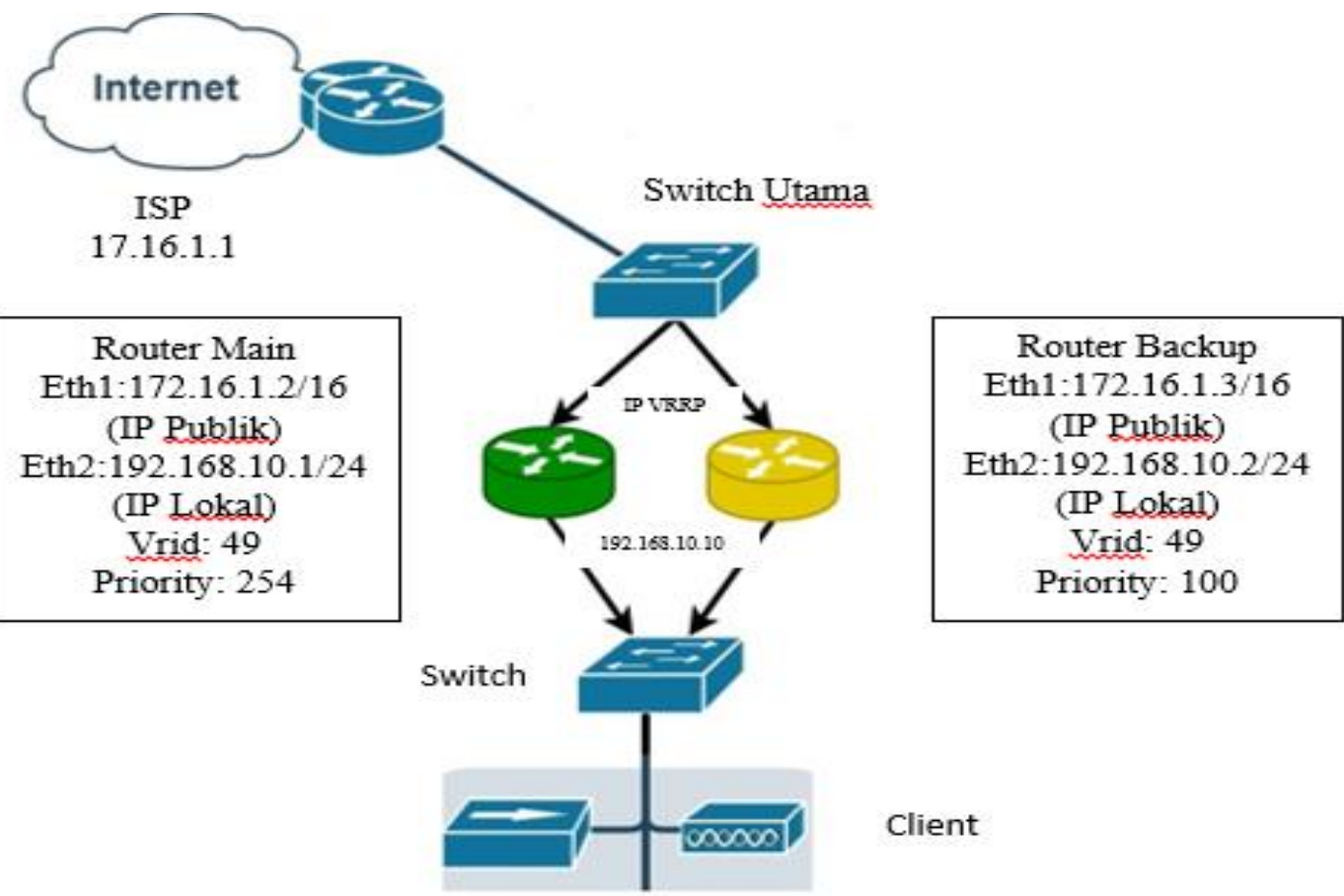

Gambar 2. Skema Jaringan Usulan VRRP

Topologi Jaringan VRRP diatas yang diusulkan pada kantor Direktorat Hukum Angkatan Darat (Ditkumad) Jakarta, mengalami perubahan skema yang tadinya router sebagai pusat internet, dialihkan ke switch. Tetap dengan megunakan ISP dari Speedy Telkomsel $10 \mathrm{Mbps}$ dan menambahkan dua bauah router, router yang digunakan adalah mikrotik routerboard agar dapat diterapkan gateway redundancy untuk meningkatkan kinerja jaringan dan tetap menggunakan switch untuk masing-masing gedung.

Pengujian rancangan skema usulan jaringan tersebut behasil menggunakan simulasi aplikasi Cisco Packet Tracer. Simulasi tersebut merupakan sekumpulan metode dan aplikasi untuk menirukan atau mempresentasikan perilaku dari suatu sistem nyata, yang biasanya dilakukan pada komputer dengan menggunakan perangkat lunak tertentu.

Dalam merancang penelitian penulis menggunakan IP Publik (ether1) yang digunakan untuk menghubungkan ke ISP sedangkan IP local (ether2) digunakan untuk menghubungkan ke cliet. IP Publik dan IP local sama-sama merupakan IP Address untuk pengalamatan pada jaringan komputer dengan memberikan sederet angka pada komputer (host), router atau peralatan jaringan lainya. 
Tabel 1. IP Address Router dan Router Backup

\begin{tabular}{c|c|c|c|c}
\hline No. & Router & Ether1 & Ether2 & VRRP \\
\hline 1 & Router Main & 172.16 .1 .2 & 192.168 .10 .1 & 192.168 .10 .10 \\
2 & Router Backup & 172.16 .1 .3 & 192.168 .10 .2 & 192.168 .10 .10 \\
\hline
\end{tabular}

Virtual ID adalah identitas dari virtual router yang dikonfigurasikan dengan range antara 1255. Nilai VRID yang digunakan harus sama dengan router utama, agar router backup mendapatkan ID dan hak akses yang sama.

Priority adalah nilai prioritas yang digunakan pada masing-masing router master dan router backup dengan nilai range 1-255. Sedangkan nilai priority digunakan untuk menentukan router mana yang digunakan sebagai router utama. Untuk itu router utama harus memiliki nilai priority lebih tinggi dari nilai priority pada router backup. Berikut tabel nilai VRID dan nilai priority:

Tabel 2. Nilai VR ID dan Priority pada Router

\begin{tabular}{c|c|c|c|c}
\hline No & Interface & VR ID & Priority & Keterngan \\
\hline 1 & VRRP & 49 & 254 & Ruoter Main \\
2 & VRRP & 49 & 100 & Router Backup \\
\hline
\end{tabular}

Dalam mengimplementasikan Virtual Router Redundancy (VRRP) untuk peningkatan kinerja jaringan dengan menggunakan gateway redundancy, menggunakan hardware yang berupa dua buah mikrotik routerboard, dua buah switch, dan satu buah laptop. Software yang digunakan untuk mengkonfigurasi mikrotik routerboard adalah VirtualBox dan Iso mikrotik. Berikut adalah rancangan aplikasi untuk membuat VRRP dengan menggunakan gateway redundancy pada mikrotik routerboard. Konfigurasi router utama dengan memasukkan konfigurasi seperti berikut: 


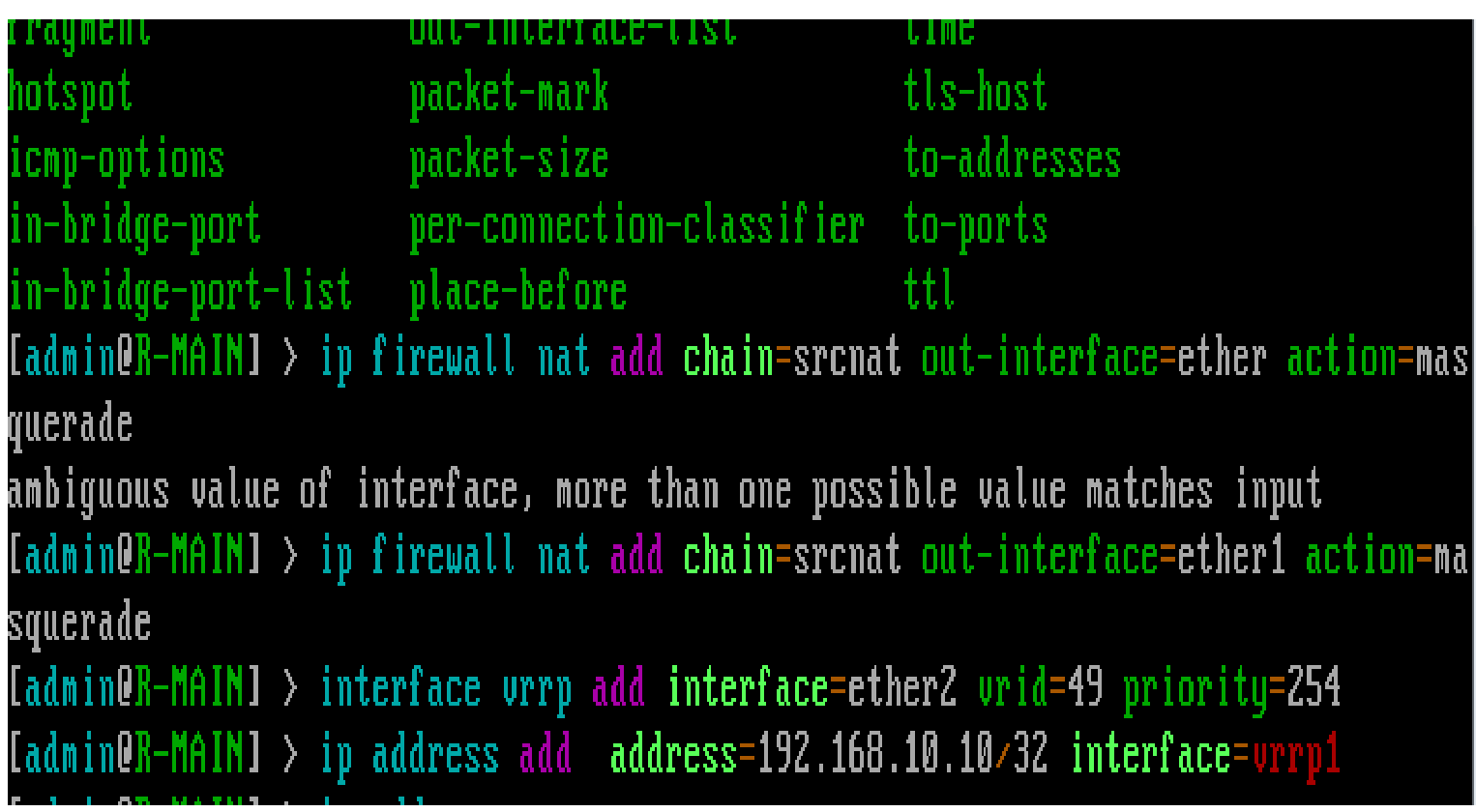

Gambar 3. Konvigurasi Router Utama

Proses konfigurasi yang diberikan terhadap router main dengan menggunakan VRID=49 dengan priority 254 dan menggunakan alamat IP address 192.168.10.10. Interface VRRP yang terhubung dengan jarinagn LAN adalah interface ether2. IP address yang digunakan pada interface VRRP nantinya akan digunakan sebagai alamat gateway terhadap jaringan local. Artinya semua client yang terhubung kedalam jaringan Direktorat Hukum Angkatan Darat (Ditkunad) nantinya akan menggunakan alamat gateway 192.168.10.10 atau alamat VRRP.

Setelah selesai melakukan konfigurasi pada router utama, selanjutanya melakukan konfigurasi yang sama terhadap router backup. Konfigurasi yang diterapkan meliputi konfigurasi terhadap ether1 yang digunakan untuk mengakeses ke internet, dan konfigurasi terhadap ether2 yang digunakan untuk jaringan local menggunakan VRRP. Berikut tahapan konfigurasi VRRP pada router backup:

[adminCR-BACKUP] $>$ interface urep add interface=ether2 urid=49 priority=100 [adminCR-BACKUP] > ip address add address=192.168,10.10/32 interface=urrp1

Gambar 4. Konfigurasi VRRP Router Backup

Gambar diatas menjelaskan proses konfigurasi yang diberikan terhadap router backup dengan menggunakan VRID=49 dengan priority 100 dan menggunakan alamat IP Address 192.168.10.10. 
Pada pengujian jaringan awal, belum diterapkan VRRP dengan menggunakan gateway redundancy. Berikut uji coba konektifitas berdasarkan jaringan berjalan :

C:4. Admınıstrator: Command Prompt

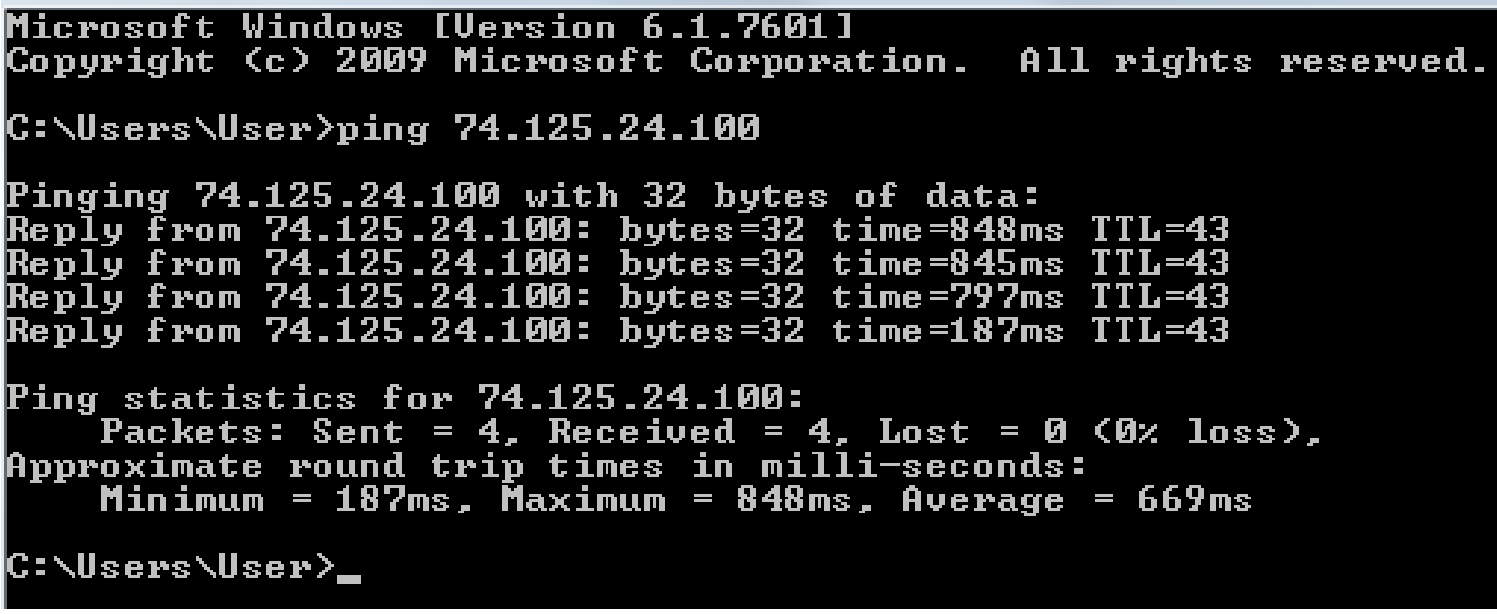

Gambar 5. Pengujian Jaringan Tanpa VRRP

Pada saat jaringan berjalan normal tidak terjadi masalah pada router utama maka jaringan akan berjalan normal dan lancar.

Pengujian jaringan berikutnya adalah pengujian jaringan berdasarkan skema jaringan usulan yang dirancang untuk Direktorat Hukum Angkatan Darat (Ditkumad) Jakarta, pada pengujian jaringan akhir ini sudah diterapkan gateway redundancy dengan menggunakan protokol VRRP. Pengujian Jaringan saat VRRP Stabil:

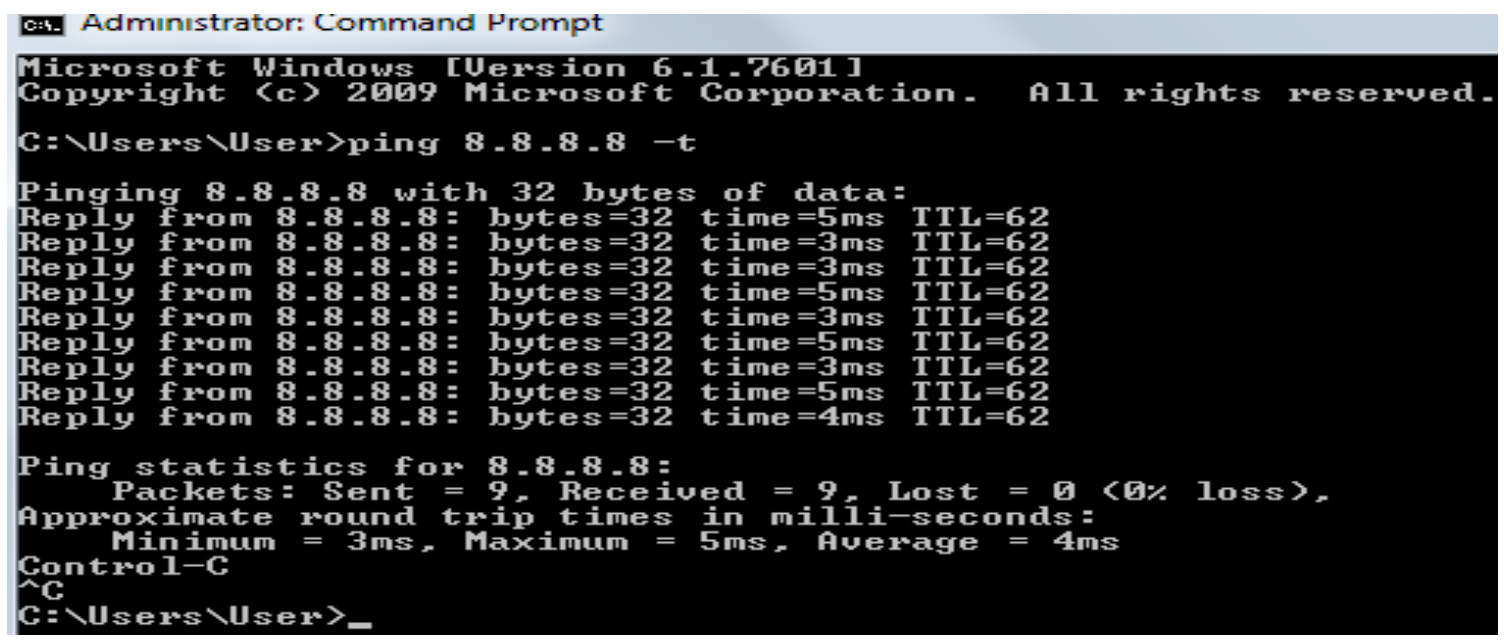

Gambar 6. Pengujian koneksi Jaringan VRRP

Pada gambar diatas menjelaskan jaringan masih stabil karena tidak adanya trouble yang menganggu konektifitas. 
Administrator: Command Prompt

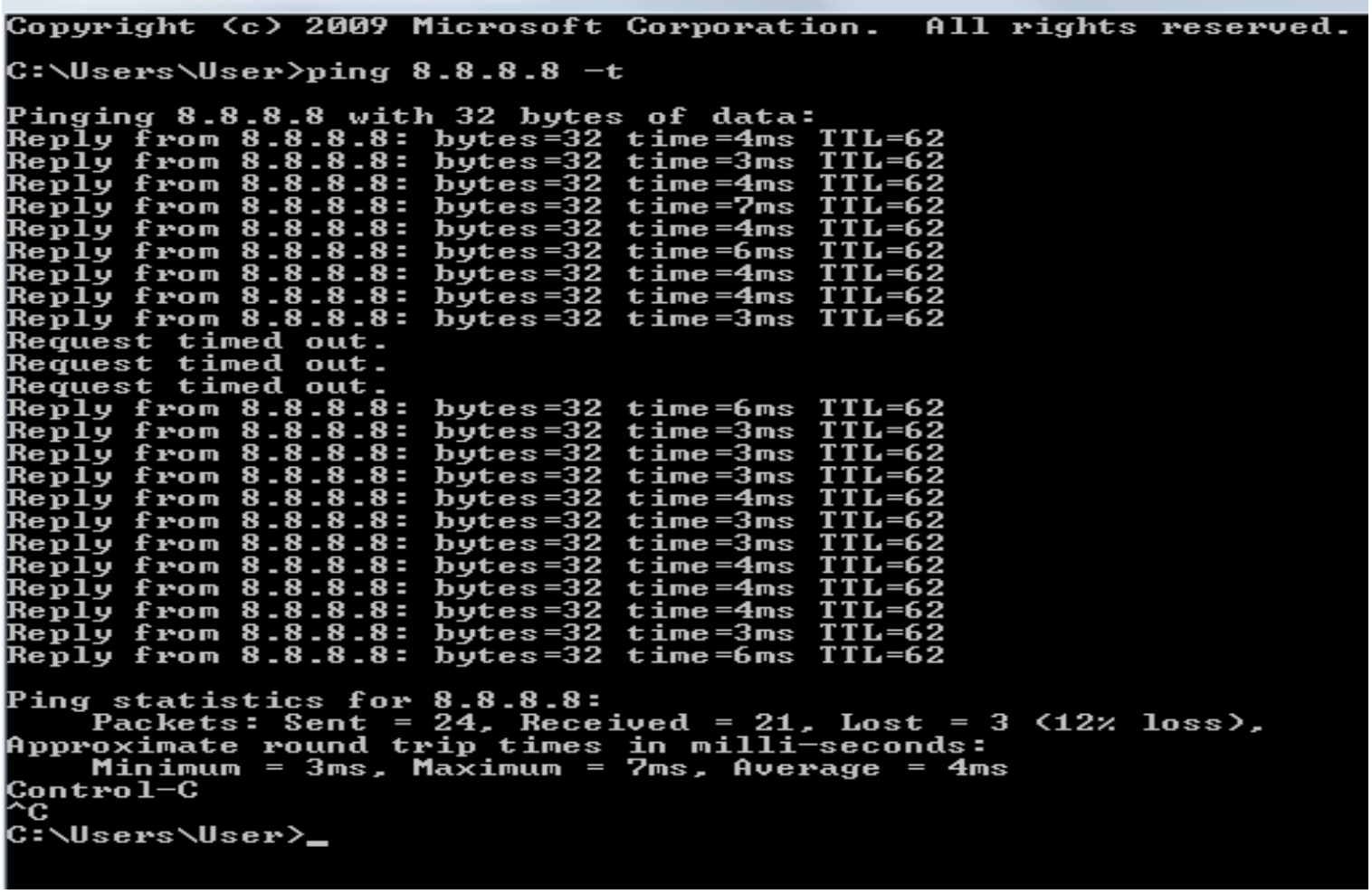

Gambar 7. Perpindahan Jaringan Router Main ke Router Backup

Pada gamabar diatas menjelaskan jika Router main tiba-tiba mengalami kegagalan jaringan dan mengaakibatkan jaringan terputus, maka Router Backup secara otomatis hanya dalam waktu seper sekian detik mengambil alih jaringan yang terputus dan langsung terkoneksi kembali.

Dapat di simpulkan bahwa kegagalan pada konektifitas jaringan tidak terlalu signifikan tergantung dari jaringan ISP yang digunakan. Saat Router Main bermasalah, waktu untuk Router backup menggantikan fungsi Router utama secara otomatis hanya seper sekian detik, jadi tidak menghambatnya jaringan yang ada di Direktorat Hukum Angkatan Darat (Ditkumad) Jakarta.

\section{KESIMPULAN DAN REKOMENDASI}

Dari hasil pengujian yang dilakukan, Virtual Router Redundancy Protocol (VRRP) dapat digunakan untuk mengatasi kegagalan perangkat yang terjadi pada salah satu jaringan dan dapat meningkatkan kinerja jaringan. Dengan menerapkan protokol VRRP saat beban router dinaikkan dan jaringan mengalami link failure, diketahui bahwa VRRP dapat bekerja dengan baik, sehingga semua proses pengiriman data tetap berjalan sebagaimana mestinya, serta VRRP dapat mejadi solusi dari perancangan jaringan telekomunikasi yang membutuhkan keandalan jaringan dari terputusnya jaringan. Kecepatan perpindahan dari router utama ke router backup, tergantung pada kualitas penyedia layanan jaringan (ISP) 
yang digunakan. Pada saat router utama mengalami kegagalan, maka secara otomatis router backup akan mengambil alih peran dari router utama. Tetapi pada saat router utama dapat berfungsi kembali, maka router utamalah yang mengambil alih peranan dari router backup tersebut.

Rekomendasi dari Mengimplementasikan gateway redundancy dengan menggunakan protocol Virtual Router Redundancy Protokol (VRRP), sebaiknya menggunakan ISP yang mempunyai kualitas yang baik. Karena lama atau cepatnya waktu perpindahan dari router utama ke router backup, tergantung dari kecepatan jaringan yang dinggunakan. Pada penelitian selanjutnya, lebih dikembangkan lagi seperti implementasi Virtual Router Redundancy Protocol. Agar jaringan komputer benar-benar stabil dan dapat diandalkan, bukan hanya dari sisi kegagalan jaringan yang digunakan, melainkan kegagalan perangkat juga. Untuk menjaga perfoma dan stabilitas jaringan pada Direktorat Hukum Angkatan Darat (Ditkumad) direkomendasikan untuk senantiasa dilakukan maintenance hardware dan software secara rutin. Juga direkomendasikan untuk memberi pelatihan kepada karyawan atau pegawai yang ditugaskan menangani jaringan di Direktorat Hukum Angkatan Darat (Ditkumad).

\section{REFERENSI}

Choirullah, Anif, \& Rochadi, (2017). Analisis Kualitas Layanan Virtual Router Redundancy Protocol Menggunakan Mikrotik pada Jaringan VLAN. Jurnal Nasional Teknik Elektro Dan Teknologi Informasi (JNTETI), 5(4), 278-285. https://doi.org/10.22146/jnteti.v5i4.275

Gustina et al (2017). Sistem Penunjang Keputusan Pemilihan Router Mikrotik Dengan Menggunakan Metode Ahp ( Analitycal Hierarchy Process ). IX(1), 68-73.

Kuswanto \& Rahman, (2019). Failover Gateway Menggunakan Protokol Virtual Router Redundancy Protocol ( VRRP ) pada Mikrotik Router. 7(1), 60-66.

Raharjo, Pernando, \& Fauzi, (2019). Perancangan Performansi Quality Of Service Dengan Metode Virtual Routing Redudancy Protocol ( VRRP ). V(1), 87-92. https://doi.org/10.31294/jtk.v4i2

Ratna, (2017). Perancangan Dan Instalasi Jaringan Local Area Network Sekolah Menengah Kejuruan Muhammadiyah Enam Gemolong Sragen. 2(2). 